International Journal of Social Science And Human Research

ISSN(print): 2644-0679, ISSN(online): 2644-0695

Volume 04 Issue 01 January 2021

DOI: $10.47191 / \mathrm{ijsshr} / \mathrm{v} 4-\mathrm{i} 1-02$

Page No : 10-17

\title{
Attitude of Muslim Students towards Sex Education in Relation to their Home Environment
}

\author{
Nishat Mehaboob ${ }^{1}$, Samsujjaman ${ }^{2}$ \\ ${ }^{1}$ B.Ed trainee, Department of Education, University of Kalyani (W.B) \\ ${ }^{2}$ Research Scholar, Department of education, University of Kalyani (W.B)
}

\begin{abstract}
The present studies intended to the find out the study and compares the attitude towards sex education of Muslim adolescence students, and also find out to compare the attitude of Muslim adolescence students towards sex education in relation to their home environment. For this study researcher was framed 2 objectives and 3 hypotheses. Normative survey method has been used in this study. 400 Muslim adolescence students were selected as sample through Purposive sampling technique .Attitude Scale towards Sex Education was developed by researcher by the help of the expert of this field and Home Environment Inventory developed by Dr. K.S. Misra were used to collect the data. The collected data was analyzed using Mean, S.D. and't' test through SPSS software. Muslim adolescence student have high attitude towards sex education. Area has affected the attitude of students towards sex education as the urban students have been found to have more favorable attitude towards sex education. Sex had not affected the attitude of rural Muslim students towards sex education. Home environment and its dimensions have affected the attitude of students towards sex education. It provides complete and healthy information for necessary life skills to deal with the problems of future life.
\end{abstract}

KEY WORDS: Attitude, Sex education, Muslim Students, Home environment.

\section{INTRODUCTION}

'Sex education is a "systematic attempt to promote the healthy awareness in the individual on the matters of his or her sexual development'-Frimpong (2010)

Today's students are the tomorrow's responsible citizens. They are the future of any nation. We know that a good classroom can give the destiny of nation a beautiful shape. That's why a good classroom should be democratic, friendly, and physicallymentally comfortable to every pupil. When students go through their adolescence period, they feel many changes in their body as well as in their friends' zone also. In this time, their curiosity level increases on everything especially on sex. They have easy access to modern technologies by which they are not only getting valuable knowledge but also they are under the dark influence of incomplete knowledge of intimate relationships. For this, they are facing lots of physical, mental as well as sexual diseases like HIV/AIDS and STDs. These diseases are increasing day by day due to the lack of proper knowledge, awareness and modes of prevention. At this present situation, to save our children, to make them secured, Sex Education is truly needed in India. Though modern science has developed very much, but till now sex is a taboo in India and sex education is a big taboo to be talked about. Here children are not allowed to have access to sexual health information because the society has the wrong concept that such exposure will spoil the child. But Sex Education helps people to gain information, skills and motivation to make healthy decisions about sex and sexuality. According to Frimpong (2010), sex education is a "systematic attempt to promote the healthy awareness in the individual on the matters of his or her sexual development, functioning, behavior and attitude through direct teaching". Similarly, the Sexuality Information and Education Council of the United States (SIECUS) in Njoku (2008), sees sex education as "a planned process of education that fosters the acquisition of factual information, the formation of positive attitudes, beliefs and values as well as the development of skills to cope with the biological, psychological, socio-cultural, and spiritual aspects of human sexuality'. From these definitions, it can be deduced that sex education is a deliberate, planned and organized learning experience in the aspect of human sexuality which is intended to equip young people with the requisite skills and adequate knowledge which will enable them to develop positive attitude on sex related issues as well as to take rational decisions in line with societal expectations. 


\section{Attitude of Muslim Students towards Sex Education in Relation to Their Home Environment}

\section{REVIEW OF RELATED STUDIES}

Many researchers have studied on the importance of sex education. Rajashree's study (2010) shows that adolescents have so many myths about the organic development systems, bodily changes, hormonal effects on reproductive system, chronological maturity and its physiological impacts. Hence sometimes they become anxious, stressful and over-pressurized. Nobody is there to help and guide. Sex-education would help students to develop positive attitude towards sex when the queries are satisfied honestly and scientifically. Randhir Kumar, Anmol Gayal, Parmal Sing, Anu Bhardwaj, Ansul Mittal, Sachin Sing Yadav's study (2014) says that sex education should be lifelong learning process based on the knowledge and skills and positive attitude. Sex education should be an integral part of the learning process beginning in childhood and continuing into adult life and its lifelong learning process.

\section{STATEMENT OF THE PROBLEM}

In recognition of the fact, the present study attempted to find out the attitude of Muslim adolescent student and also try to find out the difference between Muslim girls \& boys attitude in respect to sex education. So researcher entitle the "Attitude of Muslim Students Towards sex Education in Relation to their Home Environment"

\section{OBJECTIVES OF THE STUDY}

The objectives of the present study are given below,

1. To find out the attitude towards sex education of Muslim students on the basis of locality \& gender.

2. To compare the attitude of Muslim students towards sex education to relation their home environment.

\section{HYPOTHESIS OF THE STUDY}

Following hypotheses have been formulated. These are given below,

1. There is no significant difference in the attitude of Muslim students towards sex education.

2. There is no significant difference in the attitude of rural Muslim students towards sex education in relation to their home environment.

3. There is no significant difference in the attitude of urban Muslim students towards sex education in relation to their home environment.

\section{DEFINITIONS OF THE TERMS}

- Attitude towards Sex Education- Attitude towards sex education means the views of the people regarding the introduction of sex education in the school or college curriculum. In the present study, attitude towards sex education means the scores obtained by the college going students on Attitude Scale towards Sex Education.

- Adolescent students: adolescent is the transitional phase from childhood to adulthood that occurs between ages 13-19. According to WHO adolescent as any person between age 10-19.

- Undergraduate students- Undergraduate students mean those students who have passed Higher Secondary exam and are studying in undergraduate courses.

- Home Environment-(Home environment is a place in which an individual or a family can take rest and able to store personal property.) Home environment means the psycho-social climate of the home. Dr. K.S. Misra has given ten dimensions in his Home Environment Inventory. These ten dimensions are referred here as home environment. These are followings below-

Table 1: Ten Dimension of Home Environment Inventory

\begin{tabular}{|l|l|}
\hline Control & It indicates the autocratic atmosphere in which many restrictions are imposed by the parents. \\
\hline Protectiveness & It implies prevention of independent behavior and prolongation of infantile care. \\
\hline Punishment & It includes physical as well as affective punishment to avoid the undesirable behavior. \\
\hline Conformity & It refers to demands to work according to parents' desires and expectations. \\
\hline Social Isolation & It indicates the isolation from beloved persons except family members for negative sanctions. \\
\hline Reward & It includes material as well as symbolic rewards to increase the probability of desirable behavior. \\
\hline $\begin{array}{l}\text { Deprivation of } \\
\text { Privileges }\end{array}$ & $\begin{array}{l}\text { It implies controlling children's behavior by depriving them or their rights to seek love, respect and child } \\
\text { care from parents. }\end{array}$ \\
\hline Nurturance & $\begin{array}{l}\text { It means existence of excessive unconditional physical and emotional attachment of parents with their } \\
\text { child. }\end{array}$ \\
\hline Rejection & It implies that child has no right as a person and has no right to express his feelings. \\
\hline Permissiveness & It indicates provisions of opportunities to child to express his views freely and act according to his desires. \\
\hline
\end{tabular}




\section{Attitude of Muslim Students towards Sex Education in Relation to Their Home Environment}

These ten dimensions are the sum of the meaning of the term Home Environment. The scores, which are obtained by college going students on Home Environment Inventory, are referred as Home Environment in this present study.

\section{METHODOLOGY}

Method Used-In the present study the researcher used 'Normative survey. Here we study the attitude of graduate students of Nadia district towards sex education in relation to their home environment along with their sex and area. That's why the researcher used 'Normative survey 'method of research.

Population of the study-The population of the study is all the undergraduate students including male and female of rural and urban area of Nadia district (West Bengal).The targeted population of this study is social science group students only. Sample and Sampling Procedure-Researcher takes 400 undergraduate students including equal numbers of male and female students of rural and urban area of Nadia district as sample by purposive sampling procedure. The sampling framework is present below:

Table 2: Sampling Distribution locality and gender wise.

\begin{tabular}{|l|l|l|l|l|}
\hline Background & Area & Sex & No Of Students & Total \\
\hline \multirow{2}{*}{$\begin{array}{l}\text { College going students } \\
\text { of social science } \\
\text { background }\end{array}$} & Rural & Male & 100 & 200 \\
\cline { 2 - 4 } & Female & 100 & \\
\cline { 2 - 4 } & Urban & Male & 100 & 200 \\
\cline { 2 - 4 } & Female & 100 & 400 \\
\cline { 2 - 4 } & Total & & 400 & \\
\hline
\end{tabular}

VARIABLES: This study involves two kinds of variables which are stated below,

Independent variable-In this study, Home Environment is the independent variable. It has been measured by Home Environment Inventory developed by Dr. Karuna Shankar Misra.

Dependent variable-The attitude of under graduate students towards Sex Education, is the dependent variable. And it is measured by 'Attitude Scale towards Sex Education' developed by researcher with the help of subject expert.

Statistical Analysis: Mean, S.D. and t-test were used for the statistical analysis.

\section{SIGNIFICANT THE STUDY}

The present study may help teachers, educators, administrators, planners, policy makers, counselors, parents and students in formulating effective policies in favor of sex education in curriculum. This study will guide the Muslim adolescent's student by giving complete information that will help them to solve the problems of future life. It will help the parents and teachers to break the misconceptions about sex education in school curriculum. This study will help the policy makers to make good policies and helps them to determine their role on school curriculum. It will also help guidance workers and counselors in many ways to solve the problems of students and make their future bright and safe.

\section{RESULT \& DISCUSSION}

Table 3: Mean and S.D. of Attitude towards Sex Education of Muslim Students

\begin{tabular}{|l|l|l|l|l|l|}
\hline Variable & Area & Sex & No & Mean & Sd \\
\hline \multirow{2}{*}{$\begin{array}{l}\text { attitude towards sex } \\
\text { education }\end{array}$} & Rural & Male & 100 & 102.20 & 29.80 \\
\cline { 2 - 6 } & & Female & 100 & 107.32 & 18.80 \\
\cline { 2 - 6 } & \multirow{2}{*}{ Urban } & Male & 100 & 106.31 & 17.70 \\
\cline { 2 - 6 } & Female & 100 & 124.23 & 15.80 \\
\hline
\end{tabular}

This table shows that the urban female students have very high attitude towards sex education. Rural female students have more favorable attitude towards sex education in the comparison with rural male students. On the other hand, urban female students have also more favorable attitude than urban male students.

Table 4: Compare the Attitude of Students towards Sex Education on the basis of locality.

\begin{tabular}{|l|l|l|l|l|l|l|l|}
\hline Variable & Category & No & Mean & SD & df & t-value & Result \\
\hline $\begin{array}{l}\text { Attitude towards } \\
\text { Sex Education }\end{array}$ & Rural & 200 & 103.76 & 23.94 & 296 & $4.00^{*}$ & Significant \\
\cline { 2 - 5 } & Urban & 200 & 114.26 & 21.01 & & & \\
\hline
\end{tabular}


Attitude of Muslim Students towards Sex Education in Relation to Their Home Environment

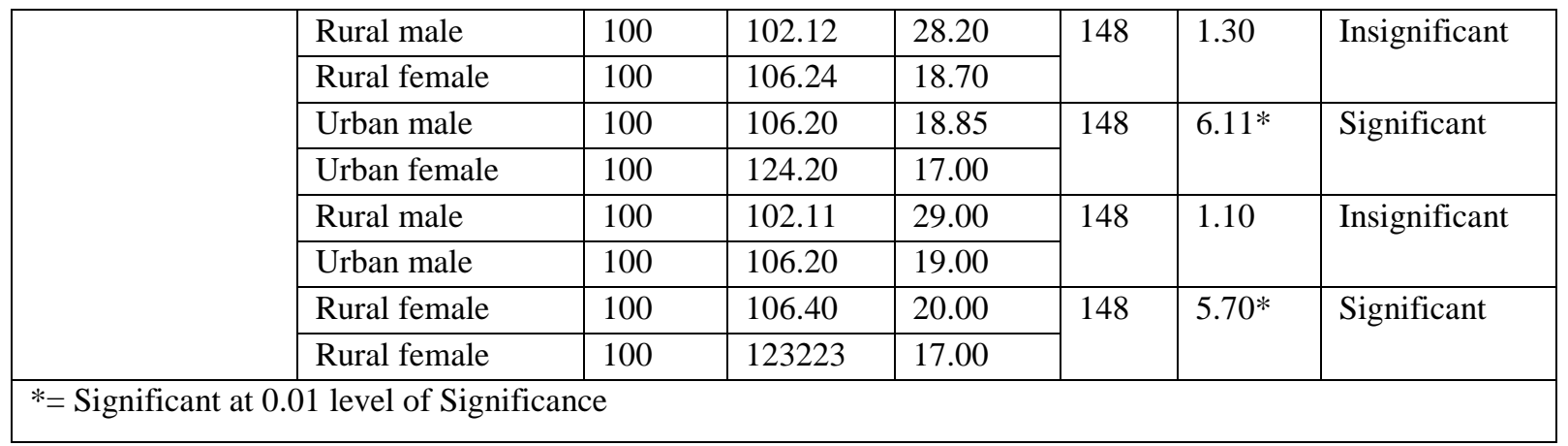

The above table exhibits the comparison of the attitude of students towards sex education. The first, third and fifth ' $t$ ' values for the attitude of students towards sex education are $4.00(\mathrm{df}=296), 6.11(\mathrm{df}=148)$ and $5.70(\mathrm{df}=148)$ respectively, which are found significant at 0.01 level of significance. It means that there is a highly significant difference between undergraduate rural and urban students, urban male and urban female students as well as rural female and urban female students on their attitude towards sex education. Mean values indicate that undergraduate urban students and urban female students have more favorable attitude towards sex education in comparison with undergraduate rural students and urban male students. Means values regarding the female students of rural and urban area indicate that urban female students have higher attitude towards sex education as compared to their rural counterparts.

On the other hand, at $\mathrm{df}=148$ the second and fourth ' $\mathrm{t}$ ' values for the attitude towards sex education are 1.30 and 1.10 respectively, which are found insignificant. It means that rural male and rural female students as well as male students of rural and urban area do not differ significantly in their attitude towards sex education.

Table 4.1: Critical ratio to compare the Attitude of Rural Students towards Sex Education in relation to their Home Environment

\begin{tabular}{|c|c|c|c|c|c|c|c|}
\hline Variable & $\begin{array}{l}\text { Dimensions of Home } \\
\text { Environment }\end{array}$ & $\begin{array}{l}\text { Level of } \\
\text { H.E }\end{array}$ & $\mathbf{N}$ & Mean & S.D. & t-value & Result \\
\hline \multirow{22}{*}{$\begin{array}{l}\text { Attitude towards } \\
\text { Sex Education }\end{array}$} & \multirow[t]{2}{*}{ Control } & Low & 52 & 92.66 & 25.17 & \multirow[t]{2}{*}{$2.81^{*}$} & \multirow[t]{2}{*}{ Significant } \\
\hline & & High & 148 & 106.77 & 24.12 & & \\
\hline & \multirow[t]{2}{*}{ Protectiveness } & Low & 106 & 102.57 & 26.52 & \multirow[t]{2}{*}{0.60} & \multirow[t]{2}{*}{ Insignificant } \\
\hline & & High & 94 & 104.97 & 23.33 & & \\
\hline & \multirow[t]{2}{*}{ Punishment } & Low & 84 & 100.94 & 26.13 & \multirow[t]{2}{*}{1.10} & \multirow[t]{2}{*}{ Insignificant } \\
\hline & & High & 116 & 105.34 & 24.24 & & \\
\hline & \multirow[t]{2}{*}{ Conformity } & Low & 137 & 104.21 & 24.54 & \multirow[t]{2}{*}{0.40} & \multirow[t]{2}{*}{ Insignificant } \\
\hline & & High & 77 & 102.62 & 26.18 & & \\
\hline & \multirow[t]{2}{*}{ Social isolation } & Low & 147 & 103.77 & 25.16 & \multirow[t]{2}{*}{0.02} & \multirow[t]{2}{*}{ Insignificant } \\
\hline & & High & 63 & 103.69 & 24.52 & & \\
\hline & \multirow[t]{2}{*}{ Reward } & Low & 123 & 103.35 & 26.47 & \multirow[t]{2}{*}{0.27} & \multirow[t]{2}{*}{ Insignificant } \\
\hline & & High & 77 & 104.42 & 22.44 & & \\
\hline & \multirow[t]{2}{*}{ Deprivation of Privilege } & Low & 105 & 101.01 & 26.75 & \multirow[t]{2}{*}{1.70} & \multirow[t]{2}{*}{ Insignificant } \\
\hline & & High & 95 & 107.35 & 22.04 & & \\
\hline & \multirow[t]{2}{*}{ Nurturance } & Low & 67 & 96.10 & 26.32 & \multirow[t]{2}{*}{$2.20 * *$} & \multirow[t]{2}{*}{ Significant } \\
\hline & & High & 133 & 106.26 & 24.07 & & \\
\hline & \multirow[t]{2}{*}{ Rejection } & Low & 55 & 92.20 & 27.06 & \multirow[t]{2}{*}{$2.60^{*}$} & Significant \\
\hline & & High & 165 & 106.07 & 23.95 & & \\
\hline & \multirow[t]{2}{*}{ Permissiveness } & Low & 119 & 103.17 & 26.55 & \multirow[t]{2}{*}{0.36} & \multirow[t]{2}{*}{ Insignificant } \\
\hline & & High & 81 & 104.62 & 22.58 & & \\
\hline & \multirow[t]{2}{*}{ Total Home Environment } & Low & 106 & 100.41 & 25.84 & \multirow[t]{2}{*}{1.74} & \multirow[t]{2}{*}{ Insignificant } \\
\hline & & High & 96 & 106.68 & 23.91 & & \\
\hline
\end{tabular}

$*$ = Significant at 0.01 level of Significance. $* *=$ Significant at 0.05 level of Significance.

The above table shows the comparison of attitude of rural students towards sex education in relation to their home environment. At df 148, the t-values to compare the attitude of rural students towards sex education having low and high level of 


\section{Attitude of Muslim Students towards Sex Education in Relation to Their Home Environment}

control ( $\mathrm{t}=2.81)$, rejection $(\mathrm{t}=2.60)$ and nurturance $(\mathrm{t}=2.20)$ have been found significant at 0.01 and 0.05 level of significance respectively. It indicates that there is a statistical significant difference in the attitude of rural students towards sex education having low and high control, rejection and nurturance. Mean values clearly show that rural students who have high control, rejection and nurturance have shown more favorable attitude towards sex education in comparison with those students, who have low control, rejection and nurturance. On the other hand, the t-values for the comparison of attitude of rural students towards sex education having low and high protectiveness $(\mathrm{t}=0.60)$, punishment $(\mathrm{t}=1.10)$, conformity $(\mathrm{t}=0.40)$, social isolation $(\mathrm{t}=0.02)$, reward $(\mathrm{t}=0.27)$, deprivation of privileges $(t=1.70)$, permissiveness $(t=0.36)$ as well as total home environment $(t=1.74)$ have been found insignificant. It suggests that rural students having low and high protectiveness, punishment, conformity, social isolation, reward, deprivation of privileges, permissiveness as well as total home environment do not differ significantly in their attitude towards sex education.

Table 5: Critical ratio to compare the Attitude of Urban Students towards Sex Education in relation to their Home Environment

\begin{tabular}{|c|c|c|c|c|c|c|c|}
\hline Variable & $\begin{array}{l}\text { Dimensions of Home } \\
\text { Environment }\end{array}$ & $\begin{array}{l}\text { Level of } \\
\text { H.E }\end{array}$ & $\mathbf{N}$ & Mean & S.D. & t-value & Result \\
\hline \multirow{22}{*}{$\begin{array}{l}\text { Attitude } \\
\text { towards } \\
\text { Education }\end{array}$} & \multirow[t]{2}{*}{ Control } & Low & 63 & 114.10 & 19.00 & \multirow[t]{2}{*}{0.40} & \multirow[t]{2}{*}{ Insignificant } \\
\hline & & High & 137 & 115.20 & 21.00 & & \\
\hline & \multirow[t]{2}{*}{ Protectiveness } & Low & 78 & 116.00 & 19.00 & \multirow[t]{2}{*}{0.45} & \multirow[t]{2}{*}{ Insignificant } \\
\hline & & High & 122 & 114.00 & 21.00 & & \\
\hline & \multirow[t]{2}{*}{ Punishment } & Low & 72 & 110.00 & 17.00 & \multirow[t]{2}{*}{1.50} & \multirow[t]{2}{*}{ Insignificant } \\
\hline & & High & 128 & 116.00 & 22.00 & & \\
\hline & \multirow[t]{2}{*}{ Conformity } & Low & 49 & 124.00 & 16.00 & \multirow[t]{2}{*}{$2.70 *$} & \multirow[t]{2}{*}{ Significant } \\
\hline & & High & 151 & 113.00 & 21.00 & & \\
\hline & \multirow[t]{2}{*}{ Social isolation } & Low & 62 & 121.00 & 17.00 & \multirow[t]{2}{*}{$1.95 * *$} & \multirow[t]{2}{*}{ Significant } \\
\hline & & High & 138 & 113.00 & 21.00 & & \\
\hline & \multirow[t]{2}{*}{ Reward } & Low & 68 & 112.00 & 18.00 & \multirow[t]{2}{*}{1.10} & \multirow[t]{2}{*}{ Insignificant } \\
\hline & & High & 142 & 116.00 & 21.00 & & \\
\hline & \multirow[t]{2}{*}{ Deprivation of Privilege } & Low & 62 & 119.00 & 14.00 & \multirow[t]{2}{*}{1.76} & \multirow[t]{2}{*}{ Insignificant } \\
\hline & & High & 148 & 114.00 & 22.00 & & \\
\hline & \multirow[t]{2}{*}{ Nurturance } & Low & 61 & 115.00 & 17.00 & \multirow[t]{2}{*}{0.10} & \multirow[t]{2}{*}{ Insignificant } \\
\hline & & High & 149 & 115.00 & 21.00 & & \\
\hline & \multirow[t]{2}{*}{ Rejection } & Low & 43 & 118.00 & 16.00 & \multirow[t]{2}{*}{0.99} & \multirow[t]{2}{*}{ Insignificant } \\
\hline & & High & 157 & 114.00 & 21.00 & & \\
\hline & \multirow[t]{2}{*}{ Permissiveness } & Low & 70 & 107.00 & 19.00 & \multirow[t]{2}{*}{$3.10^{*}$} & \multirow[t]{2}{*}{ Significant } \\
\hline & & High & 130 & 118.00 & 20.00 & & \\
\hline & \multirow{2}{*}{$\begin{array}{ll}\text { Total } & \text { Home } \\
\text { Environment } & \end{array}$} & Low & 50 & 114.00 & 17.00 & \multirow[t]{2}{*}{0.090} & \multirow[t]{2}{*}{ Insignificant } \\
\hline & & High & 150 & 115.00 & 21.00 & & \\
\hline
\end{tabular}

$*$ = Significant at $\mathbf{0 . 0 1}$ level of Significance. $* *=$ Significant at $\mathbf{0 . 0 5}$ level of Significance.

The above table shows the comparison of attitude of undergraduate urban students towards sex education in relation to their home environment. At df 148, the t-values for the comparison of the attitude of undergraduate urban students towards sex education having low and high level of conformity $(t=2.70)$, permissiveness $(t=3.10)$ and social isolation $(t=1.95)$ have been found significant at 0.01 and 0.05 level of significance respectively. It indicates that undergraduate urban students having low and high conformity; permissiveness and social isolation differ statistically and significantly in their attitude towards sex education. Mean values indicate that urban students having low conformity and social isolation and high permissiveness have shown more favorable attitude towards sex education in comparison to those students who have high conformity, social isolation and low permissiveness.

But on the other hand the t-values to compare the attitude of urban students towards sex education having low and high control $(\mathrm{t}=0.40)$, protectiveness $(\mathrm{t}=0.45)$, punishment $(\mathrm{t}=1.50)$, reward $(\mathrm{t}=1.10)$, deprivation of privileges ( $\mathrm{t}=1.76)$, nurturance $(\mathrm{t}=1.32)$, rejection $(\mathrm{t}=0.99)$ as well as total home environment $(\mathrm{t}=0.083)$ have not been found significant. It shows that urban students having low and high control, protectiveness, punishment, reward, deprivation of privileges, nurturance, rejection as well as total home environment do not differ significantly in their attitude towards sex education. 
Attitude of Muslim Students towards Sex Education in Relation to Their Home Environment

Table 6: Critical ratio to compare the Attitude of Male Students towards Sex Education in relation to their Home Environment

\begin{tabular}{|c|c|c|c|c|c|c|c|}
\hline Variable & $\begin{array}{lll}\text { Dimensions of Home } \\
\text { Environment }\end{array}$ & $\begin{array}{l}\text { Level of } \\
\text { H.E }\end{array}$ & $\mathbf{N}$ & Mean & S.D. & t-value & Result \\
\hline \multirow{22}{*}{$\begin{array}{l}\text { Attitude } \\
\text { towards Sex } \\
\text { Education }\end{array}$} & \multirow[t]{2}{*}{ Control } & Low & 58 & 97.80 & 25.30 & \multirow[t]{2}{*}{1.10} & \multirow[t]{2}{*}{ Insignificant } \\
\hline & & High & 142 & 105.00 & 24.00 & & \\
\hline & \multirow[t]{2}{*}{ Protectiveness } & Low & 104 & 104.45 & 24.45 & \multirow[t]{2}{*}{0.68} & \multirow[t]{2}{*}{ Insignificant } \\
\hline & & High & 86 & 102.50 & 24.60 & & \\
\hline & \multirow[t]{2}{*}{ Punishment } & Low & 85 & 105.20 & 24.00 & \multirow[t]{2}{*}{0.480} & \multirow[t]{2}{*}{ Insignificant } \\
\hline & & High & 115 & 104.00 & 24.91 & & \\
\hline & \multirow[t]{2}{*}{ Conformity } & Low & 80 & 103.00 & 27.47 & \multirow[t]{2}{*}{0.34} & \multirow[t]{2}{*}{ Insignificant } \\
\hline & & High & 120 & 104.70 & 22.53 & & \\
\hline & \multirow[t]{2}{*}{ Social isolation } & Low & 90 & 102.80 & 27.62 & \multirow[t]{2}{*}{0.60} & \multirow[t]{2}{*}{ Insignificant } \\
\hline & & High & 110 & 105.30 & 21.47 & & \\
\hline & \multirow[t]{2}{*}{ Reward } & Low & 110 & 103.90 & 26.30 & \multirow[t]{2}{*}{0.166} & \multirow[t]{2}{*}{ Insignificant } \\
\hline & & High & 90 & 104.50 & 22.30 & & \\
\hline & \multirow[t]{2}{*}{ Deprivation of Privilege } & Low & 110 & 103.50 & 26.92 & \multirow[t]{2}{*}{0.46} & \multirow[t]{2}{*}{ Insignificant } \\
\hline & & High & 90 & 103.10 & 21.67 & & \\
\hline & \multirow[t]{2}{*}{ Nurturance } & Low & 52 & 99.20 & 26.72 & \multirow[t]{2}{*}{1.40} & \multirow[t]{2}{*}{ Insignificant } \\
\hline & & High & 148 & 105.00 & 23.76 & & \\
\hline & \multirow[t]{2}{*}{ Rejection } & Low & 52 & 102.50 & 28.13 & \multirow[t]{2}{*}{0.44} & \multirow[t]{2}{*}{ Insignificant } \\
\hline & & High & 148 & 102.50 & 23.71 & & \\
\hline & \multirow[t]{2}{*}{ Permissiveness } & Low & 95 & 100.50 & 26.50 & \multirow[t]{2}{*}{1.50} & \multirow[t]{2}{*}{ Insignificant } \\
\hline & & High & 105 & 105.20 & 21.50 & & \\
\hline & \multirow[t]{2}{*}{ Total Home Environment } & Low & 80 & 101.50 & 26.20 & \multirow[t]{2}{*}{1.11} & \multirow[t]{2}{*}{ Insignificant } \\
\hline & & High & 120 & 106.00 & 24.00 & & \\
\hline
\end{tabular}

The above table shows the comparison of attitude of male students towards sex education in relation to their home environment. At df 148, the t-values for the comparison of the attitude of undergraduate male students towards sex education having low and high level of control $(\mathrm{t}=1.10)$, protectiveness $(\mathrm{t}=0.68)$, punishment $(\mathrm{t}=0.480)$, conformity $(\mathrm{t}=0.334)$, social isolation $(\mathrm{t}=0.60)$, reward $(\mathrm{t}=0.166)$, deprivation of privileges $(\mathrm{t}=0.405)$, nurturance $(\mathrm{t}=1.32)$, rejection $(\mathrm{t}=0.44)$, permissiveness $(\mathrm{t}=1.50)$ and total home environment $(\mathrm{t}=1.11)$ have not been found significant. It indicates that there is no significant difference in the attitude of undergraduate male students towards sex education having low and high control, protectiveness, punishment, conformity, and social isolation, and reward, deprivation of privileges, nurturance, rejection, permissiveness and total home environment.

Table 7: Critical ratio to compare the Attitude of Female Students towards Sex Education in relation to their Home Environment.

\begin{tabular}{|c|c|c|c|c|c|c|c|}
\hline Variable & $\begin{array}{l}\text { Dimensions of Home } \\
\text { Environment }\end{array}$ & $\begin{array}{l}\text { Level of } \\
\text { H.E }\end{array}$ & $\mathbf{N}$ & Mean & S.D. & t-value & Result \\
\hline \multirow{14}{*}{$\begin{array}{l}\text { Attitude } \\
\text { towards Sex } \\
\text { Education. }\end{array}$} & \multirow[t]{2}{*}{ Control } & Low & 50 & 107.25 & 20.15 & \multirow[t]{2}{*}{$1.96 * *$} & \multirow[t]{2}{*}{ Significant } \\
\hline & & High & 150 & 116.40 & 20.12 & & \\
\hline & \multirow[t]{2}{*}{ Protectiveness } & Low & 65 & 113.65 & 23.10 & \multirow[t]{2}{*}{0.43} & \multirow[t]{2}{*}{ Insignificant } \\
\hline & & High & 145 & 115.29 & 19.30 & & \\
\hline & \multirow[t]{2}{*}{ Punishment } & Low & 65 & 111.40 & 18.90 & \multirow[t]{2}{*}{1.35} & \multirow[t]{2}{*}{ Insignificant } \\
\hline & & High & 145 & 116.20 & 20.85 & & \\
\hline & \multirow[t]{2}{*}{ Conformity } & Low & 101 & 112.65 & 20.40 & \multirow[t]{2}{*}{1.40} & \multirow[t]{2}{*}{ Insignificant } \\
\hline & & High & 99 & 117.20 & 20.21 & & \\
\hline & \multirow[t]{2}{*}{ Social isolation } & Low & 105 & 112.10 & 20.40 & \multirow[t]{2}{*}{1.80} & \multirow[t]{2}{*}{ Insignificant } \\
\hline & & High & 95 & 117.80 & 19.98 & & \\
\hline & \multirow[t]{2}{*}{ Reward } & Low & 71 & 110.20 & 20.44 & \multirow[t]{2}{*}{2.00} & \multirow[t]{2}{*}{ Insignificant } \\
\hline & & High & 109 & 117.10 & 19.98 & & \\
\hline & \multirow[t]{2}{*}{ Deprivation of Privilege } & Low & 68 & 112.70 & 19.90 & \multirow[t]{2}{*}{0.79} & \multirow[t]{2}{*}{ Insignifican } \\
\hline & & High & 142 & 115.60 & 20.55 & & \\
\hline
\end{tabular}


Attitude of Muslim Students towards Sex Education in Relation to Their Home Environment

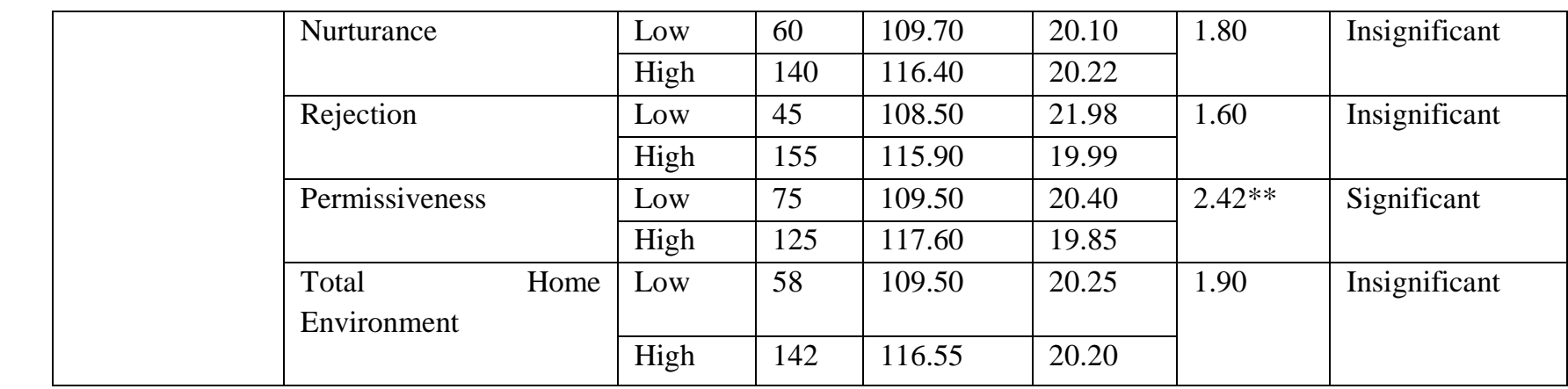

$* *$ = Significant at 0.05 level of Significance.

The above table shows the comparison of attitude of female students towards sex education in relation to their home environment. At df 148, the t-values for the comparison of the attitude of undergraduate female students towards sex education having low and high level of control $(\mathrm{t}=1.96)$ and permissiveness $(\mathrm{t}=2.42)$ have been found significant at 0.05 level of significance. It reveals a significant difference in the attitude of undergraduate female students towards sex education having low and high control and permissiveness. Mean values indicate that female students having high control and permissiveness have shown more positive attitude towards sex education.

On the other hand, the $\mathrm{t}$-values for the comparison of the attitude of female students towards sex education having low and high level of protectiveness $(\mathrm{t}=0.43)$, punishment $(\mathrm{t}=1.32)$, conformity $(\mathrm{t}=1.40)$, social isolation $(\mathrm{t}=1.80)$, reward $(\mathrm{t}=2.00)$, deprivation of privileges $(\mathrm{t}=0.771)$, nurturance $(\mathrm{t}=1.80)$, rejection $(\mathrm{t}=1.60)$ and total home environment $(\mathrm{t}=1.90)$ have been found insignificant. It indicates that there is no significant difference in the attitude of female students towards sex education having low and high protectiveness, punishment, conformity, social isolation, reward, deprivation of privileges, nurturance, rejection and total home environment.

Findings of the Study:

On the basis of the analysis and interpretation of the data, following conclusions are presented as below:

1) Urban Muslim female students have shown very high positive attitude towards sex education. And other undergraduate have been found to have high attitude towards sex education.

2) The urban Muslim students have been found to have more favorable attitude towards sex education. Because Area has affected the attitude of undergraduate students towards sex education.

3) Sex had not affected the attitude of rural Muslim students towards sex education but it has put a significant influence on the attitude of urban Muslim students towards sex education. Urban Muslim female students have exhibited more positive attitude towards sex education.

4) Control has affected the rural Muslim students', rural male students', urban male and female students' as well as total female students' attitude towards sex education. Highly controlled rural students, rural male students, urban male and female students as well as total female students have shown more positive attitude towards sex education.

5) Urban male students' attitude has been affected towards sex education by Protectiveness. Urban male students who are less protected have been found to have more favorable attitude towards sex education.

6) Urban female students of the category of high punishment have been found to have more positive attitude towards sex education. But it has not been found to affect the attitude of other students towards sex education.

7) Conformity has affected the attitude of rural female students, urban students and urban male students towards sex education. These students having low conformity have more favorable attitude towards sex education.

8) attitude of rural female students, urban students and urban male students also affected Social isolation. Less isolated rural female students, urban students and urban male students have exhibited more favorable attitude towards sex education.

9) Reward has affected the attitude of urban male and female students towards sex education. Male students who are less rewarded and female students who are highly rewarded have shown more positive attitude towards sex education.

10) Deprivation of privilege has affected the urban male students' attitude towards sex education. Urban male students who are less deprived have shown more favorable attitude towards sex education.

11) Nurturance has affected the rural students', rural and urban male students' and urban female students' attitude towards sex education. Highly nurtured rural students, rural male students and urban female students but less nurtured urban male students have exhibited more favorable attitude towards sex education.

12) Rejection has affected the attitude of rural students, rural and urban male students and urban female students towards sex education. Rural students, rural male students and urban female students having high level of rejection have shown more favorable attitude towards sex education but urban male students having low rejection have shown more positive attitude towards sex education. 


\section{Attitude of Muslim Students towards Sex Education in Relation to Their Home Environment}

13) Permissiveness has affected the attitude of urban students, urban female students and total female students towards sex education. Urban students, urban female students as well as total female students who have high permissiveness have exhibited more favorable attitude towards sex education.

14) Home environment has affected the attitude of urban male and female students towards sex education. Urban male students having low home environment have shown more positive attitude towards sex education while urban female students having high home environment have shown more favorable attitude towards sex education.

\section{DELIMITATIONS OF THE STUDY}

1. The study is delimited to the Muslim student.. (West Bengal).

2. The study has included undergraduate students only

\section{DISCUSSION}

Sex Education is truly much needed for students in the present context. Hence Inclusion of sex education has always been issue of controversy and present study has found the same. Rural students' attitude towards sex education has been found comparatively low. Some rural students think that sex education invites sexual crime and it doesn't help in family planning. Many rural pupils think that inclusion of sex education in school or college curriculum is against of Indian traditional culture. This study shows that urban students especially girls students shows their favorable attitude towards inclusion of sex education. Because, they are not stereotyped and they judge anything in the view of science. They think that sex education will not arise sexual crime; moreover it will help to reduce the sexual crime, sexual diseases. It will help the students to acquire a full knowledge and helps to achieve a scientific and positive attitude towards sex education.

\section{REFERENCE}

1) Amesh,Omale(2015), a survey of the perception of students on the study of sex education in secondary school social students in dekina loca; l government area of kogi state.international journal of education learning and development,3(1),pp $67-74$

2) Frimpong, S. O(2010). Adolescents' attitudes towards sex education: a study of senior high schools in Kumasi metropolis. Journal of Psychologia. 18(1).

3) Jimmy, E. Abeshi, et.al.(2013).Perception of students', teachers' and parents' towards sexuality education in colabar south local government area of Cross River State, Nigeria. Journal of Sociological Research 4(2):225-40.

4) Koronya, C. (2007). Determining the knowledge and attitudes of peer youth educators towards sexuality education in Kenya. Sexuality Leadership Development, Post Fellowship, Mini Project, 2007; 2: 1-28

5) Kumar,P.\& Mittal,A.(2015), a study of attitude towards sex education of college going students in relation to their home environment. international journal of current research review,7(14) pp-(7-20).

6) Mahajan, P. and Sharma, N. (2005) Awareness level of adolescent girls regarding HIV/AIDS: a comparative study of rural and urban areas of Jammu. J. Hum. Ecol. 2005; 17(4): 313-14.

7) Majova, C.N. (2002), Secondary school learners' attitudes towards sex education. Dissertation, Master of Education (Educational Psychology), University of Zululand, South Africa.

8) Toor, K. K (2012). A study of the attitudes of teachers, parents and adolescents towards sex education. MIER Journal of Educational Studies Trends \& Practices 2 (2): 177-89. 